Journal of Biotechnology and Strategic Health Research

Araştırma Makalesi / Research Article

http://dergipark.org.tr/tr/pub/bshr

\title{
Menenjit Şüpheli Hastaların Beyin Omurilik Sıvısı Örneklerinde Menenjit Paneli ile Etkenlerin Araştırılması
}

\section{Investigation of Agents By Meningitidis Panel In Cerebrospinal Fluid Samples of Patients with Suspected Meningitis}

\section{(iD) Yeliz Tanrıverdi Çaycı, (iD Muhammet Samet Emre Daştan, (iD Demet Gür Vural, (iD) Kemal Bilgin, (D) Asuman Birinci}

Ondokuz Mayıs Üniversitesi, Tıbbi Mikrobiyoloji Ana Bilim Dalı, SAMSUN

ORCID ID: Yeliz Tanrıverdi Çaycı https://orcid.org/0000-0002-9251-1953, Muhammet Samet Emre Daştan https://orcid.org/0000-00029251-1953, Demet Gür Vural https://orcid.org/0000-0003-2974-6589, Kemal Bilgin https://orcid.org/0000-0002-8892-2223, Asuman Birinci https://orcid.org/0000-0002-8653-4710

^Sorumlu Yazar / Corresponding Author: Yeliz Tanrıverdi Çaycı, e-posta / e-mail: yeliztanriverdi@gmail.com

Geliş Tarihi / Received : 30-04-2021 Kabul Tarihi / Accepted: 29-06-2021 Yayın Tarihi / Online Published: 30-08-2021

Tanrıverdi Çaycı Y., Daştan M.S.E., Gür Vural D., Bilgin K., Birinci A. Menenjit Şüpheli Hastaların Beyin Omurilik Sıvısı Örneklerinde Menenjit Paneli ile Etkenlerin Araștırılması, J Biotechnol and Strategic Health Res. 2021;5(2):98-104

\footnotetext{
Özet

Amaç Menenjit, beyni saran meningeal zarların ve spinal kordun enflamasyonudur. Bakteri, virüs ve mantarlar gibi pek çok etken menenjite yol açabilir. Menenjit; antimikrobiyal ve destek tedavi yöntemlerinde elde edilen gelismelere rağmen hala ciddi mortalite ve morbidite nedeni olmaya devam etmektedir. Bu sebeple menenjitte tedaviye erken başlangıc mortalite ve morbiditenin düşürülmesi için çok önemlidir. Bu çalsşmada hastanemiz mikrobiyoloji laboratuvarına gönderilen beyin omurilik sıvısı örneklerinde (BOS) RealTime polimeraz zincir reaksiyonu (PZR) yöntemi ile tespit edilen menenjit etkenlerin değerlendirilmesi amaçlanmıştır.

Materyal ve Bu çalışmada 01/08/2019-30/09/2020 tarihleri arasında Ondokuz Mayıs Üniversitesi Tip Fakültesi Moleküler Mikrobiyoloji Tanı Laboratuvarı̉na gönderilen 169 hastanın BOS

Metod örneği çalışmaya dahil edilmiștir. Çalıșmada Real-Time PZR yöntemi ile çalıșan SmartCycler by Cepheid cihazıyla BOS örnekleri çalıṣılmıștır. Bu sistemde Streptococcus pneumoniae, Neisseria menengitidis, Haemophilus influenza, Herpes simplex-1 (HSV-1), Herpes simplex-2 (HSV-2), Human herpes virüs type-6 (HHV-6), Epstein barr virüs (EBV), Varicella zoster virüs (VZV) ve Sitomegalo virüs (CMV) etkenleri tespit edilebilmektedir.

Bulgular Çalışmaya 169 hastanın BOS örneği dahil edilmiștir. Çalışmamıza dahil edilen hastaların \%50.88'i erkek, \%49.12'si kadın hastalardan oluşmaktadır. Hastalarımızın \%63.90’ı $<18$ yaş grubu hastalardan, $\% 36.10^{\prime} \mathrm{u}$ ise $>18$ yaș grubu hastalardan oluşmaktadır. PZR sonucuna göre pozitiflik saptanan hasta sayısı 20 olup pozitiflik oranı $\% 11.83$ tür. Pozitiflik saptanan örneklerin \%40'nı S. pneumoniae, \%20'sini HSV-1, \%15'ini N. menengitidis, \%5'ini EBV , \%5'ini H. influenzae, \%5'ini HHV-6, \%5'ini, HSV-2 ve \%5'ini VZV olușturmaktadır

Sonuc Menenjit hastalarında uygun ve yeterli antimikrobiyal tedavi için öncelikle etkenin belirlenmesi gerekmektedir. PZR gibi moleküler yöntemlerle etkenlerin erken saptanması mümkündür ve bu alanda PZR’nın sağladığı erken tanı avantajından yararlanılmalıdır.

Anahtar PZR, Menenjit, Beyin omurilik sıvisı

Kelimeler

Özet

Aim Meningitis is an inflammation of the meningeal membranes and spinal cord that surround the brain. Meningitis; despite advances in antimicrobial and supportive treatment methods, it is still a serious cause of mortality and morbidity. For this reason, emergency treatment in meningitis is very important in reducing mortality and morbidity. In this study, it was aimed to evaluate the factors detected by Real-Time PCR method in cerebrospinal fluid(CSF) samples that are sent to our hospital's microbiology laboratory.

Material and In this study, CSF samples of 169 patients who were sent to Ondokuz Mayls University Microbiology Laboratory between 01/08/2019-30/09/2020 were included. In the study, CSF samples were Method studied with the SmartCycler by Cepheid working with Real-Time PCR method. In this system, Streptococcus pneumoniae, Neisseria meningitidis, Haemophilus influenza, Herpes simplex-1 (HSV-1), Herpes simplex-2(HSV-2), Human herpes virus type-6(HHV-6), Epstein barr virus(EBV), Varicella zoster virus(VZV) and Sitomegalo virus(CMV) factors can be detected.

Results CSF samples of 169 patients were included in the study. $63.90 \%$ of our patients are patients in the $<18$ age group, and $36.10 \%$ are patients in the $>18$ age group. The number of PCR positive patients results were 20 and the positivity rate was $11.83 \%$. Positive samples consist of $40 \%$ S. pneumoniae, $20 \% \mathrm{HSV}-1,15 \% \mathrm{~N}$. meningitides, 5\% EBV, 5\% H. influenzae, 5\% HHV-6,5\% HSV-2 and 5\% VZV.

Conclusion In meningitis patients, the agent must first be determined for appropriate and adequate antimicrobial treatment. It is possible to detect the factors early with molecular methods such as PCR, and the early diagnosis advantage provided by PCR should be used in this field.

Keywords PCR, Meningitis, Cerebrospinal fluid
} 


\section{GIIRIŞ}

Santral sinir sistemi (SSS) enfeksiyonları; menenjit, ensefalit, meningoensefalit, SSS absesi, subdural-epidural abse, postenfeksiyoz ensefalomiyelit ve SSS'nin yavaş ilerleyen enfeksiyonları gibi pek çok farklı şekilde karşımıza çıkabilir. Bu klinik tablolar her yaşta görülebilmekte ve enfeksiyonun tipine göre akut, subakut veya kronik olarak karşımıza çıkabilmektedir ${ }^{1-2}$. Menenjit; beyin-omurilik sıvısının inflamasyonu olarak tanımlanır. Akut pürülan menenjitlerde etken olarak genellikle bakteriler tespit edilirken; akut aseptik menenjitlerde etken genellikle virüslerdir. Akut bakteriyel menenjit olgularının \%80-85 inden Streptococcus pneumoniae, Neisseria meningitidis ve Haemophilus influenza sorumludur ancak yaşa göre ve altta yatan koşullara göre etkenlerin görülme sıklığı farklılık göstermektedir ${ }^{3-4}$. Aseptik menenjit olgularının ise \%80-95'inden polio dişı enterovirusların sorumlu olduğu bildirilmiştir ${ }^{5}$. SSS enfeksiyonları antimikrobiyal ve destek tedavi yöntemlerinde elde edilen gelişmelere rağmen hala ciddi mortalite ve morbidite nedeni olmaya devam etmektedir ${ }^{6}$. Bu sebeple SSS enfeksiyonlarının tanısı hızlı bir şekilde konulmalı ve doğru tedavi verebilmek açısından etken mümkün olduğunca hızlı bir şekilde tespit edilmelidir. SSS enfeksiyonlarının tanısında hücre sayımı, Gram ve Aside rezistant boyama (ARB) boyama, bakteriyel kültür ve nükleik asit tespitine yönelik PZR gibi birçok yöntem kullanılmaktadır. PZR'nin diğer yöntemlere göre birçok avantajı bulunmaktadır. Örneğin; PZR' nin, bakteri kültürüne karşı en büyük avantajı hızlı sonuçlanması, canlı bakteriye ihtiyaç duymaması ve yüksek duyarlılığa sahip olmasıdır ${ }^{7}$. Bu nedenle son yıllarda en sık kullanılan yöntem olmuştur ${ }^{2-8}$. PZR yüksek duyarlılık ve özgüllüğe sahip bir yöntem olmasından dolayı birçok laboratuvarda BOS'da S. pneumoniae, N. menengitidis, H. influenza, Herpes simpleks tip-1 (HSV-1), Herpes simpleks tip-2 (HSV2), Human herpes virüs tip-6 (HHV-6), Epstein barr virüs (EBV), Varicella zoster virüs (VZV), Sitomegalovirüs (CMV), Cryptococcus neoformans, Escherichia coli, Listeria monocytogenes gibi çeşitli bakteriyel, fungal ve viral etkenler tespit edilebilmektedir ${ }^{9}$ Bu çalışmada Ondokuz Mayıs
Üniversitesi Tıp Fakültesi Hastanesi Mikrobiyoloji Laboratuvarı́na multipleks PZR yöntemi ile bakteriyel ve viral etkenlerin araştırılması için gönderilen BOS örneklerinde elde edilen sonuçların retrospektif olarak değerlendirilmesi amaçlanmıştır.

\section{YÖNTEM}

Bu çalışmada 01/08/2019 - 30/09/2020 tarihleri arasında Ondokuz Mayıs Üniversitesi Tıp Fakültesi Moleküler Mikrobiyoloji Tanı Laboratuvarı'na gönderilen 169 hastanın BOS örneği retrospektif olarak değerlendirilmiştir. Hastalara ait klinik ve laboratuvar bulguları otomasyon sisteminden elde edilmiştir. Çalışmada Real-Time PZR yöntemi ile çalışan SmartCycler(Cepheid, ABD) cihazı ile BOS örnekleri çalışılmıştır. (hangi ekstraksiyon ve PCR kiti kullanılmış belirtilmeli) $\mathrm{Bu}$ sistemde S. pneumoniae, $N$. menengitidis, $H$. influenza, Herpes simpleks tip-1 (HSV-1), Herpes simpleks tip-2 (HSV-2), Human herpes virüs tip-6 (HHV-6), Epstein barr virüs (EBV), Varicella zoster virüs (VZV) ve Sitomegalovirüs(CMV) etkenleri tespit edilebilmektedir. BOS örnekleri üretici firma önerileri doğrultusunda çalışılmıştır.

BOS örnekleri kan kültür şişesinde kültür için Mikrobiyoloji laboratuarına gönderilmiştir. Gönderilen örnekler BacT/Alert (Biomeriux, Fransa) kan kültür cihazında inkübe edilmiştir. Üreme saptanan örnekler koyun kanlı agar, eozin metilen blue agar ve çikolata agara ekimleri yapılmıştır ve $36^{\circ} \mathrm{C}$ 'de 24 saat inkübe edilmiştir. Bakterilerin tanımlanması Vitek MS (Biomeriux, Fransa) ve antimikrobiyal duyarlılıkları Vitek2 Compakt (Biomeriux, Fransa) otomatize sistemlerinde çalışılmıştır.

Santrifüj edilmemiş örneklerden hücre sayımı ve gram boyama yapılmıştır.

Çalışma için Ondokuz Mayıs Üniversitesi Tip Fakültesi Klinik Araştırmalar etik kurul onayı alınmıştır (B.30.2.ODM.0.20.08/318). 


\section{BULGULAR}

Çalışmaya 169 hastanın BOS örneği dahil edilmiştir. Çalışmamıza dahil edilen hastaların \%50.88'i erkek, \%49.12'si kadın hastalardan oluşmaktadır. Hastalarımızın \%63.90’1 $<18$ yaş grubu hastalardan, $\% 36.10$ 'u ise $>18$ yaş grubu hastalardan oluşmaktadır (Tablo 1). PZR sonucuna göre pozitiflik saptanan hasta say1sı 20'dir (\%11.83). Pozitiflik saptanan örneklerin \%40’ını S. pneumoniae, \%20'sini HSV-1, \%15'ini N. menengitidis, \%5'ini EBV, \%5'ini $H$. influenza, \%5'ini HHV-6, \%5'ini HSV-2 ve \%5'ini VZV oluşturmaktadır. S. pneumoniae pozitif saptanan etkenler içerisinde \%40 oranla ilk sırada yer alırken HSV-1 \%20 ile ikinci sırada, N. menengitidis \%15 ile üçüncü sırada yer almıştır (Şekil 1). Pozitiflik saptanan BOS örneklerinden 12 örnek için bakteriyel kültür istemi de yapılmış ve sadece bir örnekte üreme tespit edilmiştir. Bu üreme de PZR sonucu ile örtüşecek şekilde S. pneumoniae olmuştur. Gram boyalı mikroskobik incelemelerde 10 örnekte $(\% 62,5)$ lökosit varlığı saptanmıştır. Gram boyama incelemesi yapılan örneklerin hiçbirinde mikroorganizma görülememiştir. Boyasız hücre sayma lamı ile yapılan mikroskobik incelemede ise BOS örneklerinin dokuz tanesinde (\%75) lökosit tespit edilmiş olup polimorfo nükleer lökosit(PMNL) oranı bu dokuz örneğin tamamında \%70 ve üzeri bulunmuştur, bu örnekler PZR ile bakteriyel etken pozitifliği saptanan örneklerdir.

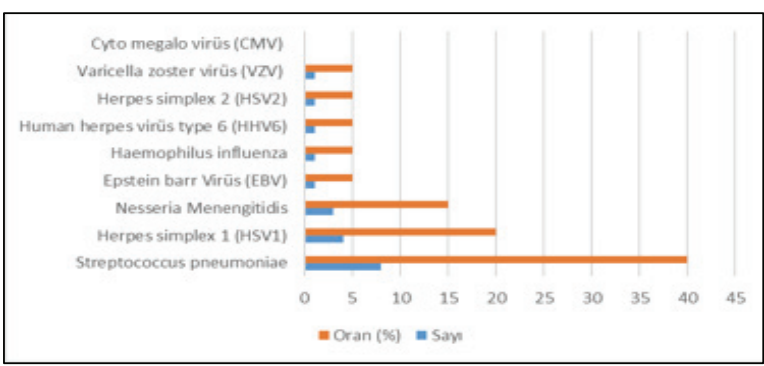

Şekil 1. BOS örneklerinde saptanan etkenlerin dağılımı

Çalışmamızda pozitif etken saptanan 20 hastadan bir tanesi vefat ederken; diğer 19 hasta uygun tedaviler ile sağlıklarına kavuşup taburcu edilmişlerdir. Vefat eden hastada saptanan etken $S$. pneumoniae'dir.

Laboratuvarımıza gönderilen örneklerin geldikleri servislerin dağılımına bakıldığında en çok örneğinin çocuk acil servisinden ( $n=39, \% 23.07)$ gönderildiği onu çocuk genel servisi ( $n=35, \% 20.71)$ ve nöroloji servisinin $(n=25$, $\% 14.80$ ) takip ettiği görülmüştür (Tablo 2). Örneklerden izole edilen etkenlerin kliniğe göre dağılımına baktığımızda S. pneumoniae'nın en sık izole edilen etken olduğu $(\mathrm{n}=8, \% 40)$ ve en sık çocuk acil servisinden $(\mathrm{n}=4, \% 20)$ gönderildiği saptanmıştır (Tablo 3).

\begin{tabular}{|c|c|c|c|c|c|c|c|}
\hline \multirow[t]{2}{*}{ ETKEN } & \multicolumn{7}{|c|}{ YAŞ DAĞILIMI } \\
\hline & $0-5$ & $5-18$ & $18-25$ & $25-45$ & $45-65$ & $>65$ & TOPLAM \\
\hline S. pneumoniae & 2 & 2 & - & 1 & 3 & - & 8 \\
\hline N. menengitidis & - & 2 & - & - & 1 & - & 3 \\
\hline H. influenza & - & - & - & 1 & - & - & 1 \\
\hline HSV1-Tip 1 & 1 & 1 & - & - & 2 & - & 4 \\
\hline HSV2-Tip 2 & 1 & - & - & - & - & - & 1 \\
\hline HHV6 & 1 & - & - & - & - & - & 1 \\
\hline EBV & - & - & - & 1 & - & - & 1 \\
\hline VZV & - & - & - & - & - & 1 & 1 \\
\hline CMV & - & - & - & - & - & - & - \\
\hline TOPLAM & 5 & 5 & - & 3 & 6 & 1 & 20 \\
\hline
\end{tabular}


J Biotechnol and Strategic Health Res. 2021;5(2):98-104

ÇAYCI, DAŞTAN, VURAL, BİLGİN, BİRINCİ, Menenjit Etkenlerinin Araştırılması

\begin{tabular}{|l|c|c|}
\hline Tablo 2. Örneklerin gönderildiği kliniklerin dağılımı & ORAN(\%) \\
\hline SERVis & HASTA SAYISI & 20.72 \\
\hline Çocuk Acil servisi & 39 & 14,80 \\
\hline Çocuk Genel Servisi & 35 & 11.83 \\
\hline Nöroloji servisi & 25 & 7,69 \\
\hline Enfeksiyon Hastalıkları servisi & 20 & 6,50 \\
\hline Çocuk Enfeksiyon servisi & 13 & 4,73 \\
\hline Çocuk Yoğun Bakım servisi & 11 & 4,15 \\
\hline Acil ve İlkyardım servisi & 8 & 2,36 \\
\hline Çocuk Nöroloji servisi & 7 & 1,78 \\
\hline Nöroloji Yoğun Bakım servisi & 4 & 0,59 \\
\hline Yenidoğan Yoğun Bakım servisi & 3 & 0,59 \\
\hline Beyin Cerrahisi servisi & 1 & 0,59 \\
\hline Genel Cerrahi servisi & 1 & 0,59 \\
\hline Nefroloji servisi & 1 & 100 \\
\hline Hematoloji servisi & 1 & \\
\hline TOPLAM & & 169 \\
\hline
\end{tabular}

\begin{tabular}{|c|c|c|c|c|c|c|c|c|}
\hline \multirow[b]{2}{*}{ ETKEN } & \multicolumn{8}{|c|}{ Klinik } \\
\hline & Dahiliye & $\begin{array}{l}\text { Enfeksiyon } \\
\text { hastalıklar1 }\end{array}$ & Nöroloji & Çocuk Acil & $\begin{array}{c}\text { Çocuk } \\
\text { Nöroloji }\end{array}$ & $\begin{array}{c}\text { Acil ve } \\
\text { İlkyardım }\end{array}$ & $\begin{array}{c}\text { Çocuk } \\
\text { Enfeksiyon }\end{array}$ & Toplam \\
\hline S. pneumoniae & 1 & 1 & 1 & 4 & - & 1 & - & 8 \\
\hline N. menengitidis & - & 1 & - & 1 & 1 & - & - & 3 \\
\hline H. influenza & - & - & 1 & - & - & - & - & 1 \\
\hline HSV1-Tip 1 & - & 2 & - & 1 & - & - & 1 & 4 \\
\hline HSV2-Tip 2 & - & - & - & 1 & - & - & - & 1 \\
\hline HHV6 & - & - & - & 1 & - & - & - & 1 \\
\hline EBV & 1 & - & - & & - & - & - & 1 \\
\hline VZV & - & 1 & - & - & - & - & - & 1 \\
\hline CMV & - & - & - & - & - & - & - & - \\
\hline TOPLAM & 2 & 5 & 2 & 8 & 1 & 1 & 1 & 20 \\
\hline
\end{tabular}

\section{TARTIŞMA}

Tiptaki gelişmelere rağmen menenjit/meningoensefalitler uzun süre hastanede yatışa neden olan, yüksek fatalite oranına sahip, ciddi sekeller birakabilen, tedavisi zaman alabilen bir enfeksiyon hastalığıdır ${ }^{10}$. Bakteri, virüs ve mantarlar gibi pek çok etken menenjite yol açabilir. Akut bakteriyel menenjit tanısında BOS kültürü altın standart olmakla birlikte beraberinde getirdiği bazı dezavantajlar da vardır. Bu duruma; tanı koymada gecikme, ampirik tedavi alan hastalarda etkenlerin üretiminde zorluk, hastanın ampirik olarak gereğinden fazla tedavi alması gibi durumlar örnek olarak gösterilebilir ${ }^{2-8-11}$. Virüslerle birlikte bakterilerin de hızlıca tanımlanabilmesi için son zamanlarda PZR yöntemine ağırlık verilmeye başlanmıştır ${ }^{12}$. PZR gibi amplifikasyon yöntemleri ile bakteri ve virüslerin nükleik asitlerin BOS’ta saptanma oranları yükselmiştir ${ }^{13}$. Çalışmamızdaki 169 hastanın BOS örneğinin 19 tanesinde toplam 20 pozitif (\%11.83) bakteriyel ya da viral bir etken 
tespit edilmiştir. Bir hastamızda 2 etken aynı anda tespit edilmiş olup bu etkenler S. pneumonia ve $H$. influenzae'dır. Ülkemizde konu ile ilgili yapılan çalışmalarda ağırlıklı olarak çocuk ya da erişkin yaş gruplarında görülen viral ya da bakteriyel etkenler olarak ayrı ayrı ele alınmıştır. Ülkemizde menenjitlerin etiyolojisine yönelik araştırmalar çoğunlukla çocuk hasta grubunu kapsamaktadır ve bizim çalışmamızda da ülke genelindeki çalışmalarla örtüşecek şekilde çocuk hasta popülasyonu daha büyük kısmı oluşturmaktadır. Ancak çalışmamızda Akkaya ve ark'nın ${ }^{6}$ yaptığı çalışma gibi hem erişkin hem de çocuk hastaları kapsayıp; bakteriyel ve viral etkenler aynı anda tespit edilmiştir. Yeni doğan dönemi hariç bakteriyel menenjit vakalarının \%80'inden fazlasina S. pneumoniae, H. influenzae tip b ve N. meningitidis neden olmaktadir ${ }^{14-15}$. S. pneumoniae toplum kaynaklı bakteriyel menenjitlerin en sık etkenidir10. Akkaya ve ark'nın ${ }^{6}$ yaptığı çalışmada 7 (\%3.5) hastada $S$. pneumoniae etken olarak bulunmuş ve bakteriyel menenjit etkenleri arasında ilk sırada yer almıştır. Yine aynı çalışmada viral etkenler arasında Enterovirüsler \%25 oranla menenjit etkenlerinin ilk sırasında yer almıştır. Sarınoğlu ve ark'nın ${ }^{16} 2016$ yılında yaptığı BOS örneklerinde saptanan viral etkenler adlı çalışmada 12 (\%34.2) hastada HSV1 en fazla saptanan etken olurken; bunu sekiz (\%22.8) hastada saptanan Enterovirus takip etmiştir. 2012 yılında Y.Duman ve ark'nın ${ }^{10}$ yaptıkları retrospektif çalışmada yirmi beş hastada Koagülaz negatif stafilokok (KNS) en fazla saptanan etken olurken; bunu 11 hastada saptanan S. pneumoniae takip etmiştir. Soylar ve $\operatorname{ark'nın~}^{17}$ yaptı̆̆ı çalışmada EBV \%15 oranla en yüksek yüzdeye sahip etken olmuştur. Bizim çalışmamızda ise virüslerden en sık etken (\%20) HSV-1 iken; bakterilerde ise (\%40) S. pneumoniae bulunmuştur. Wu ve ark'nın ${ }^{18}$ yaptığg çalışmada 451 BOS örneği incelenmiş ve bu örneklerin 113 tanesinde real time PZR ile pozitiflik saptanmış olup etkenlerin dağılımı $S$. pneumoniae $(\mathrm{n}=51), N$. meningitidis $(\mathrm{n}=57)$ H. influenzae $(n=5)$ olacak sekilde tespit edilmiştir. Bu çalışmada kültüre kıyasla; real time PZR'nın duyarlılık ve özgüllüğü sırasıyla \%95 ve \%90 olarak bulunmuştur. Yine aynı çalışmada real time PZR ve Gram boyama yöntemlerinin hastaların kullandığı antibiyotik tedavilerinden kültüre kıyasla çok daha az etkilendiği sonucuna varılmıştır. Mısır'da yapılan başka bir çalışmada şüpheli bakteriyel menenjit vakalarından alınan kültür negatif 40 BOS örneği real time PZR ile sırasıyla çalışılmış S. pneumoniae, H. influenzae ve N. meningitidis için spesifik lytA, bexA ve ctrA genlerinin varl1ğ 1 incelenmiştir. Kültür negatif BOS örneklerinin 36’sında (\%90) S. pneumoniae için real time PZR sonuçları pozitif tespit edilirken; $H$. influenzae ve $N$. meningitidis tespit edilememiştir. Real time PZR ile dört(\%10) örnek negatif çımıştır ${ }^{19}$.

Bir yıl içinde bakteriyel menenjit tanısı alan olguların \%71'inin hastane kaynaklı olduğu ve bunların \%28'inde etkenin üretilebildiği, toplum kaynaklı menenjit tanısı alan olguların ise \%1 olduğu belirlenmiştir. Toplum kaynaklı menenjit olgusunda (\%1) etkenin kültürde üretilmeyip PZR ile saptanması ve bunun Gram boyama sonucunu da desteklemesi ile PZR'nin kültürden daha fazla avantaj sağladığ yaptıkları çalışmada menenjitli hastalarda etken dağılımı incelendiğinde S. pneumonia(\%27), H. influenza(\%11) ve N. meningitidis(\%11) oranlarında bildirilmiştir. Aseptik menenjit olgularında en sık tespit edilen etken grubu virüslerdir ${ }^{5}$. İngiltere'de yapılan ve BOS'ta viral etkenlerin araştırıldığı bir çalışmada 1683 BOS örneği incelenmiş ve 33 hastada HSV-2, 25 hastada ise HSV-1 saptanmıştır. Ülkemizde yapılan çalışmalarda da HSV önemli bir menenjit etkeni olarak bulunmuştur ${ }^{3}$. Çiçek ve ark'nın ${ }^{22}$ yaptığ başka bir çalışmada akut menenjit tanısı olan hastaların \%33'ünde virüslerin etken olduğu, bunların \%22.5'nin Enterovirüs, \%9.9'unun Herpes virüsler ve \%8.1'nin Batı nil virüsü (BNV) olduğu görülmüştür. Erişkin ve çocuk grubu ile ve cinsiyete göre pozitiflik oranları arasında istatistiksel olarak anlamlı bir fark bulunmamıştır.

Sonuç olarak menenjit günümüzde hala önemli bir sağl1k sorunudur. Menenjite bağlı mortalite ve morbiditeyi azaltmak için erken tanı ve tedavi çok önemlidir. Bu sebeple menenjit şüpheli hastalarda, PZR gibi moleküler yöntem- 
J Biotechnol and Strategic Health Res. 2021;5(2):98-104

ÇAYCI, DAȘTAN, VURAL, BİLGİN, BİRİNCI, Menenjit Etkenlerinin Araștırılması

lerle etkenlerin erken saptanması mümkün görünmekte-

dir. 
J Biotechnol and Strategic Health Res. 2021;5(2):98-104

\section{References}

1. Smalling TW, Sefers SE, Li H, et al. Molecular approaches to detecting herpes simplex virus and enteroviruses in the central nervous system. J Clin Microbiol. 2002; 40:23172322.

2. Us AD. Viral santral sinir sistemi enfeksiyonları. Moleküler, Klinik ve Tanısal Viroloji,1. Baskı, Us AD, Ergünay K (Ed), Ankara. Bilimsel Tip Yayınevi, 2012; s.271-294.

3. Gültepe B, Bayram Y, Güdücüoğlu $H$, ve ark. Bir üniversite hastanesinde bakteriyel ve viral menenjit etkenlerinin farklı PCR yöntemleri ile araştırılması. Abant Med J. 2015; 4:125-129.

4. Soylar M, Altuğlu İ, Sertöz R, ve ark. Ege Üniversitesi Hastanesỉne başvuran santral sinir sistemi enfeksiyonu olgularında saptanan viral etkenler. Ege Tip Dergisi. 2014; 53:65-70.

5. Kılıç I, Altuğlu I, Ciçek C, ve ark. Santral sinir sistemi enfeksiyonu etkeni enterovirusların RT-PCR ve hücre kültür yöntemleri ile saptanması. Mikrobiyol Bul. 2011; 45:468-477.

6. Akkaya O, Güvenç Hİ, Güzelant A, ve ark. Menenjit Etkenlerinin Real-Time Pcr Yöntemiyle Araştırılması. Türk Mikrobiyol Cem Derg, 2017; 47(3): 131-137.

7. Amin M, Ghaderpanah M, Tahereh Navidifar T. Detection of Haemophilus influenzae type b, Streptococcus agalactiae, Streptococcus pneumoniae and Neisseria meningitidis in CSF specimens of children suspicious of meningitis in Ahvaz, Iran. Kaohsiung J Med Sci. 2016; 32:501-506.

8. Chadwick DR. Viral meningitis. Brit Med Bul. 2006; 75-76:1-14

9. Delbue S, Tremolada S, Ferrante P. Application of molecular tools for the diagnosis of central nervous system infections. Neurol Sci. 2008; 29(2):283-285.

10. Duman Y, Yakupoğulları Y, Tekerekoğlu MS, ve ark. Bir üniversite hastanesi laboratuvarında beyin omurilik sıvısı’nda izole edilen mikroorganizmaların üç yıllık geriye dönük analizi. Dicle Tip Dergisi. 2012; 39 (1):70-74.

11. Furyk JS, Swann O, Molyneux E. Systematic review: neonatal meningitis in the developing world. Trop Med Int Health. 2011; 16(6): 672-679.

12. Brouwer MC, Tunkel AR, van de Beek D. Epidemiology, diagnosis, and antimicrobial treatment of acute bacterial meningitis. Clin Microbiol Rev. 2010; 23(3):467-492.
13. Sayıner AA. Viral merkezi sinir sistemi infeksiyonlarında tanı. Ankem Derg. 2005; 19(2):130-136.

14. Tunkel AR, Scheld WM. Acute meningitis. Mandell, Douglas and Bennett.s Principles and Practice of Infectious Diseases, 6.baskı, GL Mandell, RG Douglas, JE Bennett (Ed), New York. Churchill Livingstone, 2005; s.1083- 1126.

15. Harrison LH. Prospects for vaccine prevention of meningococcal infection. Clin Microbiol Rev. 2006; 19(1):142-164.

16. Sarinoğlu RC, Sağlık İ, Mutlu D, ve ark. Beyin Omurilik Sıvısı Örneklerinden Saptanan Viral Etkenler. Türk Mikrobiyol Cem Derg. 2016; 46(4):152-158.

17. Soylar M, Altuğlu İ, Sertöz R, ve ark. Ege Üniversitesi Hastanesỉne başvuran santral sinir sistemi enfeksiyonu olgularında saptanan viral etkenler. Ege Tip Dergisi. 2014; 53(2):65-

18. Wu HM, Cordeiro SM, Harcourt BH, et al. Accuracy of real-time PCR, Gram stain and culture for Streptococcus pneumoniae, Neisseria meningitidis and Haemophilus influenzae meningitis diagnosis. BMC Infect Dis. 2013;13(1):1-10.

19. Khater WS, Elabd SH. Identification of common bacterial pathogens causing meningitis in culture-negative cerebrospinal fluid samples using real-time polymerase chain reaction. Int J Microbiol, 2016; Article ID 4197187. doi: 10.1155/2016/4197187

20. Toprak S, Can K, Calıșan R, ve ark. Menenjit Tanısı Almıs Hastalarda, Bakteriyel Menenjit Etkenlerinin Kültür ve PZR ile Belirlenmesi. Türk Mikrobiyol Cem Derg. 2019; 49(4):191-196.

21. Özdemir H, Tapsız A, Çiftçi E, ve ark. Çocuklarda akut bakteriyel menenjit. Çocuk Enf Derg. 2010; 4(1): 9-14

22. Çiçek C, Pullukçu H, Kalfaoğlu H,ve ark. Akut Menenjit Kliniği ile Başvuran Hastaların BOS Örneklerinde Viral Etkenlerin Erken Tanısı. Flora. 2015; 20(4):174-181. 